\title{
Bioinorganic chemistry of synucleinopathies: Deciphering the binding features of Met motifs and His-50 in AS-Cu(I) interactions
}

\author{
Marco C. Miotto ${ }^{\mathrm{a}, \mathrm{b}}$, Andrés Binolfi ${ }^{\mathrm{c}}$, Markus Zweckstetter ${ }^{\mathrm{d}, \mathrm{e}, \mathrm{f}}$, Christian Griesinger ${ }^{\mathrm{d}}$, Claudio O. Fernández ${ }^{\mathrm{a}, \mathrm{b}, *}$

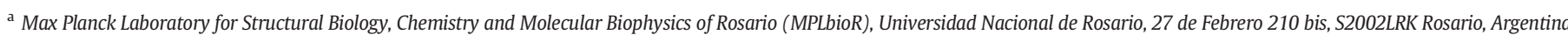 \\ b Instituto de Biología Molecular y Celular de Rosario, IBR-CONICET, Universidad Nacional de Rosario, 27 de Febrero 210 bis, S2002LRK Rosario, Argentina \\ c Department of NMR-supported Structural Biology, Leibniz Institute of Molecular Pharmacology (FMP), Robert-Roessle-Str. 10, 13125 Berlin, Germany \\ d Department of NMR-based Structural Biology, Max Planck Institute for Biophysical Chemistry, Am Fassberg 11, D-37077 Göttingen, Germany \\ e German Center for Neurodegenerative Diseases (DZNE), 37077 Göttingen, Germany \\ ${ }^{\mathrm{f}}$ Center for Nanoscale Microscopy and Molecular Physiology of the Brain (CNMPB), University Medicine Göttingen, 37073 Göttingen, Germany
}

\section{A R T I C L E I N F O}

\section{Article history:}

Received 9 July 2014

Received in revised form 25 August 2014

Accepted 25 August 2014

Available online 3 September 2014

\section{Keywords:}

Parkinson

Alpha-synuclein

$\mathrm{Cu}(\mathrm{I})$

Met-rich sites

\begin{abstract}
A B S T R A C T
The aggregation of alpha-synuclein (AS) is a critical step in the etiology of Parkinson's disease (PD) and other neurodegenerative synucleinopathies. This process is selectively enhanced by copper in vitro and the interaction is proposed to play a potential role in vivo. Presently, the identity of the $\mathrm{Cu}(\mathrm{I})$ binding sites in AS and their relative affinities are under debate. In this work we have addressed unresolved details related to the structural binding specificity and affinity of $\mathrm{Cu}(\mathrm{I})$ to full-length $\mathrm{AS}$. We demonstrated conclusively that: (i) the binding preferences of $\mathrm{Cu}$ (I) for the Met-binding sites at the $\mathrm{N}-\left(K_{\mathrm{d}}=20 \mu \mathrm{M}\right)$ and C-terminus $\left(K_{\mathrm{d}}=270 \mu \mathrm{M}\right)$ of AS are widely different: (ii) the imidazole ring of His-50 acts as an effective anchoring residue $\left(K_{\mathrm{d}}=50 \mu \mathrm{M}\right)$ for $\mathrm{Cu}(\mathrm{I})$ binding to AS; and (iii) no major structural rearrangements occur in the protein upon $\mathrm{Cu}(\mathrm{I})$ binding. Overall, our work shows that $\mathrm{Cu}(\mathrm{I})$ binding to the $\mathrm{N}$ - and $\mathrm{C}$-terminal regions of AS are two independent events, with substantial differences in their affinities, and suggest that protein oxidative damage derived from a misbalance in cellular copper homeostasis would target preferentially the $\mathrm{N}$-terminal region of AS. This knowledge is key to understanding the structural-aggregation basis of the copper catalyzed oxidation of AS.
\end{abstract}

(c) 2014 Elsevier Inc. All rights reserved.
The aggregation of alpha-synuclein (AS) is a critical step in the etiology of Parkinson's disease (PD) [1,2]. Protein-metal interactions play an important role in AS aggregation and growing evidence indicates that this process might represent the link between the pathological processes of protein aggregation, oxidative damage and neuronal cell loss [3-8]. As reported for the $A \beta$ peptide and prion protein, AS is also highly susceptible to copper-catalyzed oxidation, a reaction that induces extensive oligomerization of these proteins [9-13]. This mechanism is a highly selective, site-specific process that involves interactions of the protein with both oxidation states of the copper ion. Added to the large body of evidence supporting AS- $\mathrm{Cu}(\mathrm{II})$ interactions [14-20], elucidation of the residue-specific basis determining the $\mathrm{AS}-\mathrm{Cu}(\mathrm{I})$ structural-affinity features is central to establish a connection of the AS-copper interactions with the mechanistic basis-oxidative damage-behind the metal-enhanced AS amyloid assembly. In that direction, we have demonstrated recently that both Met residues in the motif ${ }^{1} \mathrm{MDVFM}^{5}$ constitute key structural determinants for the binding of $\mathrm{Cu}(\mathrm{I})$ to the $\mathrm{N}$-terminal

\footnotetext{
* Corresponding author at: Max Planck Laboratory for Structural Biology, Chemistry and Molecular Biophysics of Rosario (MPLbioR), Universidad Nacional de Rosario, 27 de Febrero 210 bis, S2002LRK-Rosario, Argentina. Tel.: + 54341 4237868x752.

E-mail addresses: cfernan@gwdg.de, fernandez@ibr-conicet.gov.ar (C.O. Fernández).
}

region of AS in a $\operatorname{Met}^{1}(\mathrm{~S})-\mathrm{Cu}(\mathrm{I})-(\mathrm{S}) \mathrm{Met}^{5}$ coordination environment $[21,22]$. From a comparative analysis with other binding interfaces in the protein we concluded that the ${ }^{1} \mathrm{MDVFM}^{5}$ moiety represents the high-affinity $\mathrm{Cu}(\mathrm{I})$ binding site in AS. Indeed, we found that susceptibilities of Met residues to oxidative damage in the full-length protein correlate well with their binding preferences for $\mathrm{Cu}(\mathrm{I})$ [22].

Surprisingly, a recent work in which $\mathrm{Ag}(\mathrm{I})$ was used as a probe for $\mathrm{Cu}(\mathrm{I})$ binding to AS proposed the existence of two $\mathrm{Cu}(\mathrm{I}) / \mathrm{Ag}(\mathrm{I})$ binding domains with comparable affinities $\left(K_{\mathrm{d}}\right.$ in the range $10^{-5}$ to $\left.10^{-6} \mathrm{M}\right)$, encompassing Met-1/Met-5 and Met-116/Met-127 residues at the Nand C-terminus, respectively [23]. The results were derived from a study using $\mathrm{Ag}(\mathrm{I})$ and a binary system of model peptides. Moreover, a significant structural rearrangement involving a bent backbone and induction of a $\beta$-turn conformation was calculated from the interaction of $\mathrm{Ag}(\mathrm{I})$ with a peptide containing the C-terminus Met-binding motif [23]. Finally, no evidences for $\mathrm{Ag}(\mathrm{I}) / \mathrm{Cu}(\mathrm{I})$ interactions with the region encompassing His-50 were found, leading to the conclusion that this region is not involved in $\mathrm{Cu}(\mathrm{I})$ binding [23].

These discrepancies motivated us to re-examine the bioinorganic chemistry of AS; in particular, to determine the structural and affinity features of the $\mathrm{Cu}(\mathrm{I})$ binding sites identified along the full-length protein structure. To analyze the interaction, we used ${ }^{1} \mathrm{H}-{ }^{15} \mathrm{~N}$ heteronuclear single quantum correlation (HSQC) NMR spectroscopy. 
Upon titration of ${ }^{15} \mathrm{~N}$-enriched AS with increasing concentrations of $\mathrm{Cu}(\mathrm{I})$, the ${ }^{1} \mathrm{H}-{ }^{15} \mathrm{~N}$ HSQC spectra retained the excellent resolution of the uncomplexed protein, but demonstrated measurable chemical shift changes in a discrete number of residues located at the $\mathrm{N}$ terminal and C-terminal regions (Fig. 1). No broadened or new resonances appeared. The residues exhibiting the largest displacements in the amide resonances were Val-3, Phe-4 and Met-5 (site 1), with smaller shift perturbations centered on the amide group of His-50 (site 2 ) and the region comprising residues 115-130 (site 3), that contains Met residues at positions 116 and 127. The effects on His-50 and Met-116/Met-127 amide resonances were further pronounced in samples containing 2-3 equivalents of the added metal ion. Overall, no evidences of significant structural rearrangements at the Cterminus of the protein could be derived from the analysis of the chemical shift displacements measured for the AS-Cu(I) complexes (Fig. 1 and Fig. S1A).

We then studied the interaction of $\mathrm{Cu}(\mathrm{I})$ with the mutants M116A AS and M127A AS, aiming to determine the role of these residues in directing the binding of $\mathrm{Cu}(\mathrm{I})$ to the $\mathrm{C}$-terminus (Fig. 2). Almost a complete loss of binding to the C-terminal region was observed when Met residues in positions 116 or 127 were replaced by Ala (Fig. 2B, C), demonstrating that both Met residues are important for binding of $\mathrm{Cu}(\mathrm{I})$ to that region. Conversely, removing Met residues in positions 116 or 127 did not affect the binding of $\mathrm{Cu}(\mathrm{I})$ to the binding moieties at the $\mathrm{N}$-terminal region (Fig. 2), confirming that the $\mathrm{Cu}(\mathrm{I})$ sites in AS constitute independent, non-interactive binding motifs.

From our experiments, the NMR-derived apparent affinities for the $\mathrm{Cu}(\mathrm{I})$ complexes at the Met-1/Met-5 ( site 1), His-50 (site 2) and Met-116/Met-127 (site 3) sites were $K_{\mathrm{d} 1}=20 \pm 2 \mu \mathrm{M}, K_{\mathrm{d} 2}=$ $50 \pm 5 \mu \mathrm{M}$ and $K_{\mathrm{d} 3}=270 \pm 20 \mu \mathrm{M}$, respectively (Fig. 3). These results demonstrate that the binding preferences of $\mathrm{Cu}(\mathrm{I})$ for the
Met-containing sites at the $\mathrm{N}$ - and $\mathrm{C}$-terminus of AS are widely different. Regarding the role of His-50 in $\mathrm{Cu}(\mathrm{I})$ binding, we characterized further the interaction of $\mathrm{Cu}(\mathrm{I})$ with a synthetic peptide containing the sequence $a a 45-55$ of AS. The $1 \mathrm{D}^{1} \mathrm{H}$ NMR experiments shown in Fig. S2 demonstrate that His-50 is indeed involved in $\mathrm{Cu}(\mathrm{I})$ binding $\left(K_{\mathrm{d}}=55 \pm 5 \mu \mathrm{M}\right)$, and confirm that the $\mathrm{Cu}(\mathrm{I})$ effects observed on the amide groups reflect the direct interaction of the metal ion with the imidazole ring of the histidine residue.

Finally, in order to determine the influence of $\mathrm{Cu}(\mathrm{I})$ binding on the structural features of full-length AS, we performed residual dipolar coupling (RDC) measurements. We have identified previously a residual structure at the C-terminus of AS that is stabilized by intramolecular interactions between the ${ }^{115}$ DMPVD ${ }^{119}$ and ${ }^{125}$ YEMPS $^{129}$ hydrophobic clusters and the NAC region (Fig. S1B) [24,25]. The RDC profile of the protein backbone at the $\mathrm{C}$-terminus was shown to be very sensitive to the occurrence of structural changes triggered by experimental conditions or the binding of ligands to that region $[24,26]$. Indeed, it is expected that structural rearrangements such as those proposed to occur upon $\mathrm{Cu}(\mathrm{I})$ binding to the $\mathrm{C}$-terminus will affect the conformational restrictions at that region and its associated RDC values. As shown in Fig. S1B, the invariance of the RDCs values of the protein backbone at the C-terminus confirms that $\mathrm{Cu}(\mathrm{I})$ binding to the Met-116/Met-127 motif does not trigger significant conformational changes or large structural rearrangements at that region.

In this work, we demonstrated that in full-length $\mathrm{AS}, \mathrm{Cu}(\mathrm{I})$ binds preferentially to the N-terminal Met-motif ${ }^{1} \mathbf{M D V F M}^{5}$ over the ${ }^{116}$ MPVDPDNEAYEM ${ }^{127}$ site located at the C-terminus. Our findings are consistent with previous work indicating that the affinity of Met-rich sites for $\mathrm{Cu}(\mathrm{I})$ depends not only of the number of Met residues but also the number of amino acids separating them [27-30]. Indeed, in model peptides containing two Met residues the affinity

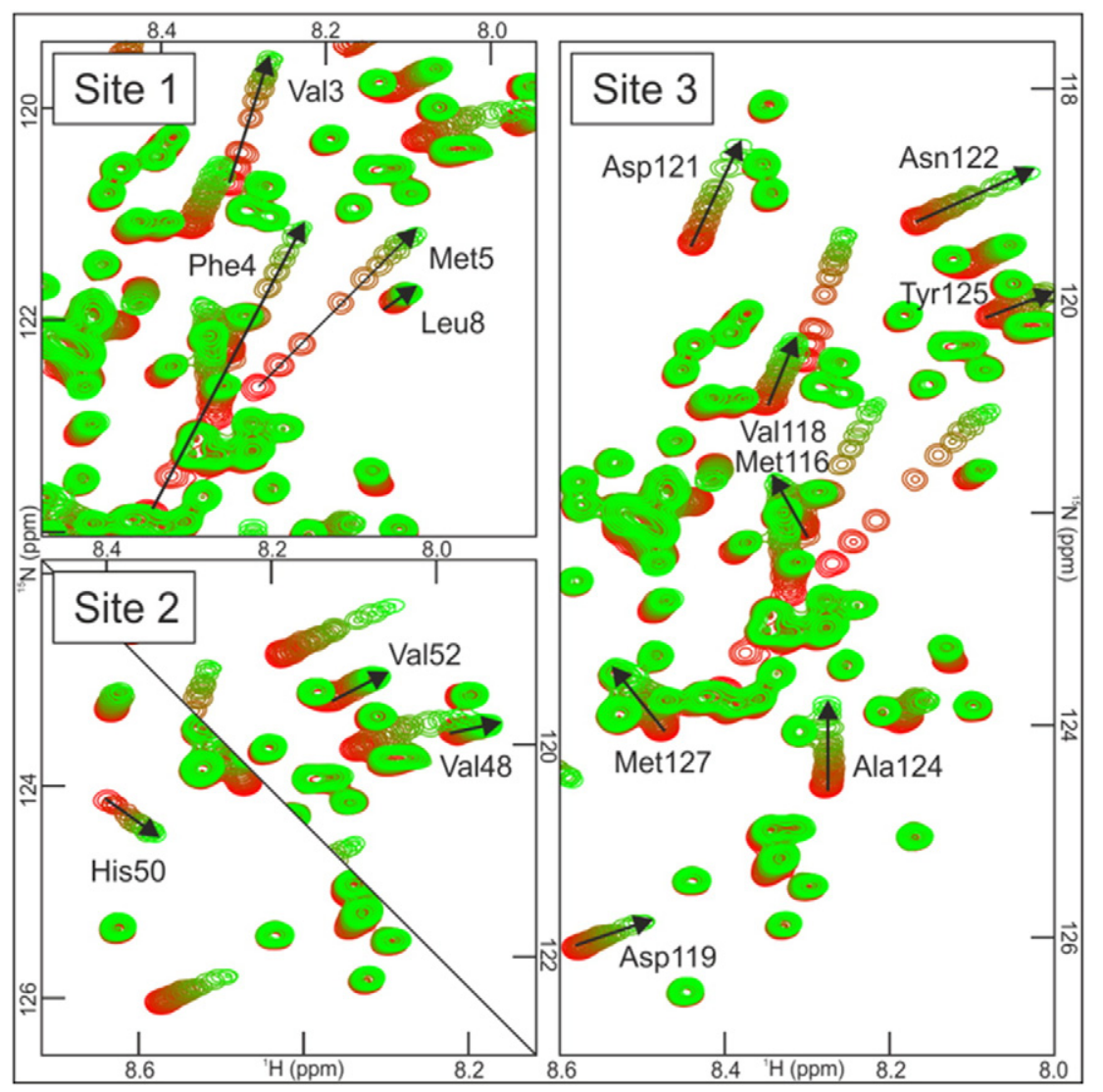

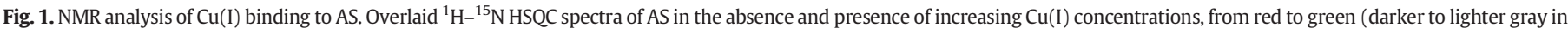

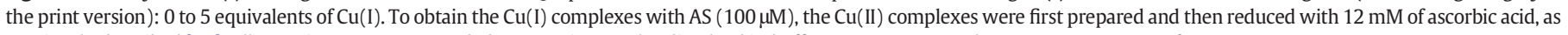
previously described [22]. All experiments were recorded on protein samples dissolved in buffer MES $20 \mathrm{mM}, \mathrm{NaCl} 100 \mathrm{mM}$, pH 6.5 at $15{ }^{\circ} \mathrm{C}$. 


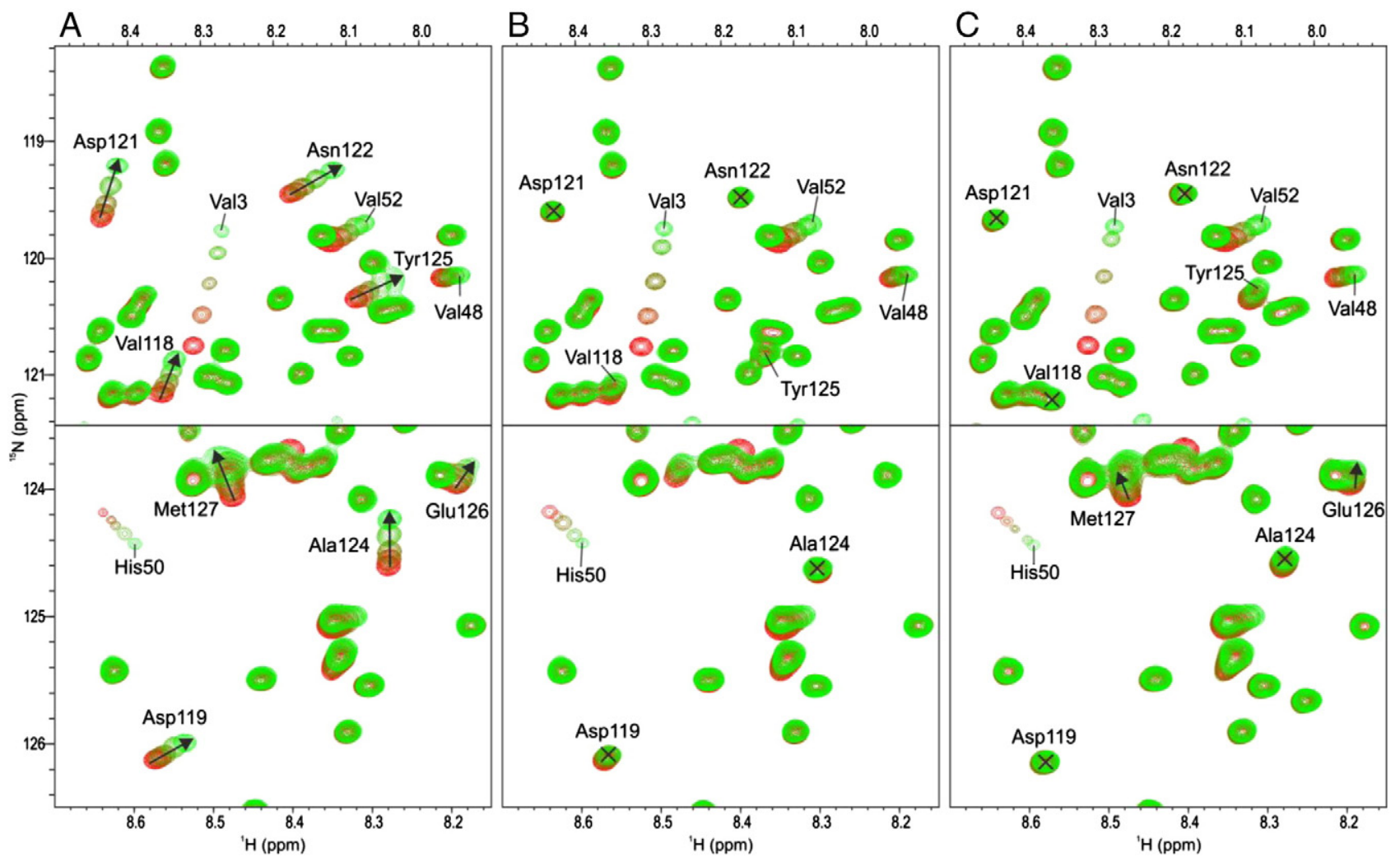

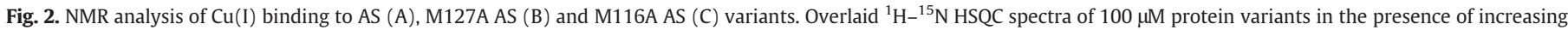

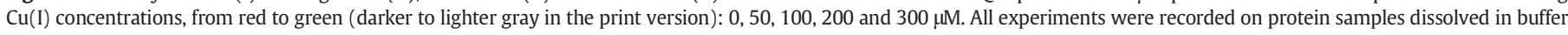

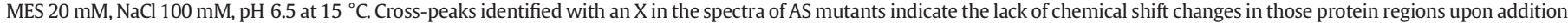
of increasing concentrations of $\mathrm{Cu}(\mathrm{I})$ ions.

was shown to range from $15-20 \mu \mathrm{M}$ to $45-50 \mu \mathrm{M}$ when the number of intervening amino acids between both Met residues changed from two to five, respectively [28]. Thus, a more drastic effect, likely the one observed in this work, might be expected for the affinity of $\mathrm{Cu}(\mathrm{I})$ to the ${ }^{116}$ MPVDPDNEAYEM ${ }^{127}$ fragment.

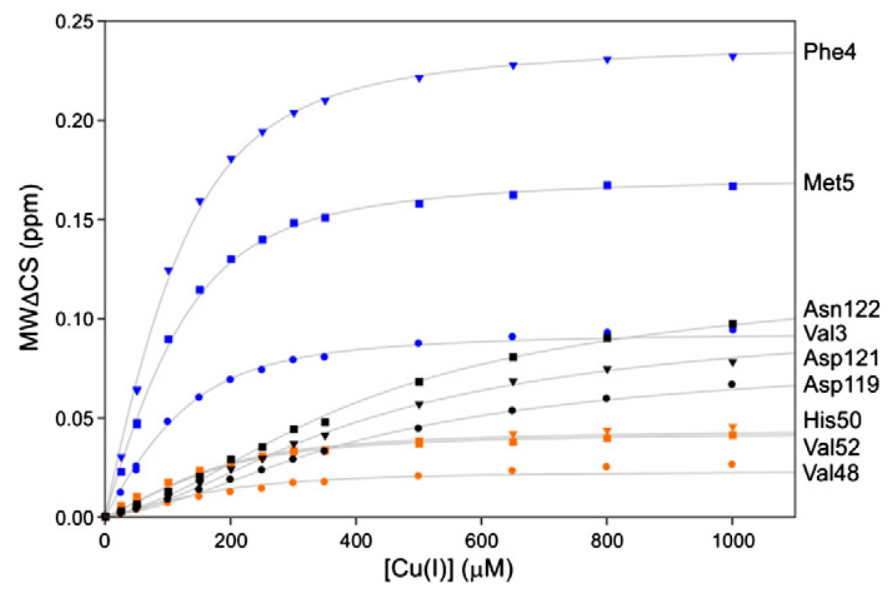

Fig. 3. Affinity features of $\mathrm{Cu}(\mathrm{I})$ binding to AS. The panel shows the binding curves of $\mathrm{Cu}(\mathrm{I})$ to sites 1,2 and 3 of $\mathrm{AS}(100 \mu \mathrm{M})$ as monitored in Fig. 1 by changes in the mean weighted chemical shift displacements (MW $\Delta \mathrm{CS}$ ) for ${ }^{1} \mathrm{H}$ and ${ }^{15} \mathrm{~N}$ of amide resonances, calculated as $\left[\left(\Delta \delta^{1} \mathrm{H}\right)^{2}+\left(\Delta \delta^{15} \mathrm{~N} / 10\right)^{2}\right]^{1 / 2}$. MW $\Delta \mathrm{CS}$ of amide resonances of Val3 (blue circle), Phe4 (blue triangle), Met5 (blue square), Val48 (orange circle), His50 (orange triangle), Val52 (orange square), Asp119 (black circle), Asp121 (black triangle) and Asn122 (black square). Curves represent the fit to a model incorporating complexes of $\mathrm{Cu}(\mathrm{I})$ into three classes of independent, non-interactive binding sites, using the program DynaFit.
Regarding the use of $\mathrm{Ag}(\mathrm{I})$ to mimic the binding effects of $\mathrm{Cu}(\mathrm{I})$ ions, competition studies based on mass spectrometry, NMR and $\mathrm{CD}$ spectroscopies demonstrated that Met-rich peptides exhibit a binding preference for $\mathrm{Ag}(\mathrm{I})$ over $\mathrm{Cu}(\mathrm{I})$ [27]. Moreover, those studies indicated that according to considerable differences in the effective ionic radii of the metal ions, $\mathrm{Cu}(\mathrm{I})$ would not be able to induce severe structural changes as those induced by $\mathrm{Ag}(\mathrm{I})$ [27], an observation that might explain some of the discrepancies discussed above. Overall, our work demonstrates that conclusions derived from strategies using $\mathrm{Ag}(\mathrm{I})$ ions and synthetic model peptides as the sole approach to mimic the effects of $\mathrm{Cu}(\mathrm{I})$ binding to full-length proteins should be considered with care.

Finally, the role of His-50 in $\mathrm{Cu}(\mathrm{I})$ binding is an important finding from our work that needs to be addressed by future studies, since the ability of histidine to bind both $\mathrm{Cu}(\mathrm{I})$ and $\mathrm{Cu}(\mathrm{II})$ in the full-length protein might make AS even more susceptible to oxidative damage by metal catalyzed oxidation.

\section{Acknowledgements}

C.O.F. thanks ANPCyT, FONCyT, CONICET, the Ministry of Education of Argentina, the Ministry of Health of Argentina (PICT 1344 and PICT 2819), the Max Planck Society (Project 10390) and the Alexander von Humboldt Foundation (P.S.BICH 4507) for financial support. C.O.F. is the Head of the Max Planck Laboratory for Structural Biology, Chemistry and Molecular Biophysics of Rosario (MPLbioR), partner of the Max Planck Institute for Biophysical Chemistry (Göttingen). M.Z. is a member of the German Center for Neurodegenerative Diseases (DZNE) and the Center for Nanoscale Microscopy and Molecular Physiology of the Brain (CNMPB), Göttingen. M.C.M. is a recipient of a fellowship from CONICET in Argentina. 


\section{Appendix A. Supplementary data}

RDC profile and chemical shifts displacements of backbone amide groups of $\mathrm{AS}-\mathrm{Cu}(\mathrm{I})$ complexes. NMR analysis of $\mathrm{Cu}(\mathrm{I})$ binding to the 45-55 AS peptide. Supplementary data to this article can be found online at http://dx.doi.org/10.1016/j.jinorgbio.2014.08.012.

\section{References}

[1] M. Goedert, M.G. Spillantini, K. Del Tredici, H. Braak, Nat. Rev. Neurol. 9 (2013) 13-24.

[2] H.A. Lashuel, C.R. Overk, A. Oueslati, E. Masliah, Nat. Rev. Neurosci. 14 (2013) 38-48.

[3] W. Yu, H. Jiang, J. Wang, J.-X. Xie, Neurosci. Bull. 24 (2008) 73-78.

[4] A. Binolfi, L. Quintanar, C.W. Bertoncini, C. Griesinger, C.O. Fernández, Coord. Chem. Rev. 256 (2012) 2188-2201.

[5] A. Binolfi, C.O. Fernández, Brain Diseases and Metalloproteins, Pan Stanford Publishing, 2012. 327-366.

[6] J.A. Wright, X. Wang, D.R. Brown, FASEB J. 23 (2009) 2384-2393.

[7] C. Wang, L. Liu, L. Zhang, Y. Peng, F. Zhou, Biochemistry 49 (2010) 8134-8142.

[8] Y. Ha, A. Yang, S. Lee, K. Kim, H. Liew, S.H. Lee, et al., J. Neurosci. Res. 92 (2014) 359-368.

[9] J.R. Requena, D. Groth, G. Legname, E.R. Stadtman, S.B. Prusiner, R.L. Levine, Proc. Natl. Acad. Sci. U. S. A. 98 (2001) 7170-7175.

[10] J.A.P. Chaves, C. Sanchez-López, M.P.B. Gomes, T. Sisnande, B. Macedo, V.E. de Oliveira, et al., J. Biol. Inorg. Chem. 19 (2014) 839-851.

[11] G. La Penna, C. Hureau, O. Andreussi, P. Faller, J. Phys. Chem. B 117 (2013) 16455-16467.

[12] L.-E. Cassagnes, V. Hervé, F. Nepveu, C. Hureau, P. Faller, F. Collin, Angew. Chem. 52 (2013) 11110-11113.

[13] H.R. Lucas, S. DeBeer, M.-S. Hong, J.C. Lee, J. Am. Chem. Soc. 132 (2010) 6636-6637.
[14] A. Binolfi, R.M. Rasia, C.W. Bertoncini, M. Ceolin, M. Zweckstetter, C. Griesinger, et al., J. Am. Chem. Soc. 128 (2006) 9893-9901.

[15] R.M. Rasia, C.W. Bertoncini, D. Marsh, W. Hoyer, D. Cherny, M. Zweckstetter, et al., Proc. Natl. Acad. Sci. U. S. A. 102 (2005) 4294-4299.

[16] A. Binolfi, G.R. Lamberto, R. Duran, L. Quintanar, C.W. Bertoncini, J.M. Souza, et al., J. Am. Chem. Soc. 130 (2008) 11801-11812.

[17] A. Binolfi, E.E. Rodriguez, D. Valensin, N. D'Amelio, E. Ippoliti, G. Obal, et al., Inorg. Chem. 49 (2010) 10668-10679.

[18] S.C. Drew, S.L. Leong, C.L.L. Pham, D.J. Tew, C.L. Masters, L.A. Miles, et al., J. Am. Chem. Soc. 130 (2008) 7766-7773.

[19] J.C. Lee, H.B. Gray, J.R. Winkler, J. Am. Chem. Soc. 130 (2008) 6898-6899.

[20] P. Davies, X. Wang, C.J. Sarell, A. Drewett, F. Marken, J.H. Viles, et al., Biochemistry 50 (2011) 37-47.

[21] A. Binolfi, A.A. Valiente-Gabioud, R. Duran, M. Zweckstetter, C. Griesinger, C.O. Fernandez, J. Am. Chem. Soc. 133 (2011) 194-196.

[22] M.C. Miotto, E.E. Rodriguez, A.A. Valiente-Gabioud, V. Torres-Monserrat, A. Binolfi, L. Quintanar, et al., Inorg. Chem. 53 (2014) 4350-4358.

[23] F. Camponeschi, D. Valensin, I. Tessari, L. Bubacco, S. Dell'Acqua, L. Casella, et al., Inorg. Chem. 52 (2013) 1358-1367.

[24] C.W. Bertoncini, Y.-S. Jung, C.O. Fernandez, W. Hoyer, C. Griesinger, T.M. Jovin, et al., Proc. Natl. Acad. Sci. U. S. A. 102 (2005) 1430-1435.

[25] P. Bernadó, C.W. Bertoncini, C. Griesinger, M. Zweckstetter, M. Blackledge, J. Am. Chem. Soc. 127 (2005) 17968-17969.

[26] M.K. Cho, G. Nodet, H.Y. Kim, M.R. Jensen, P. Bernado, C.O. Fernandez, et al., Protein Sci. 18 (2009) 1840-1846.

[27] J.T. Rubino, P. Riggs-Gelasco, K.J. Franz, J. Biol. Inorg. Chem. 15 (2010) 1033-1049.

[28] J. Jiang, I.A. Nadas, M.A. Kim, K.J. Franz, Inorg. Chem. 44 (2005) 9787-9794.

[29] J.T. Rubino, K.J. Franz, J. Inorg. Biochem. 107 (2012) 129-143.

[30] J.T. Rubino, M.P. Chenkin, M. Keller, P. Riggs-Gelasco, K.J. Franz, Metallomics 3 (2011) 61-73. 